\title{
The Teaching of Spanish as a Heritage Language: Overview of what we Need to Know as Educators
}

\author{
Aixa SAID-Mohand \\ Modern Languages Departament \\ New Jersey City University \\ USA
}

Received: 26 October 2010 / Accepted: 22 December 2010

ISSN: $1697-7467$

\begin{abstract}
In recent years, we have seen an increasing number of instructors faced with the knotty task of teaching Spanish to Heritage speakers. In order to deliver the best teaching methodology, it is important to take into account four central issues: (1) the social identity of Heritage speakers and the use of labels in academia, (2) the wide range of language proficiency among Heritage language learners, (3) the «undeveloped» academic register of Heritage learners, and (4) the all-important measurement of bilingual skills.

Keywords: Heritage Learners, language proficiency, academic and bilingual skills
\end{abstract}

La enseñanza del español como lengua familiar: lo que los profesores necesitan saber.

RESUMEN: En años recientes se ha visto un incremento de profesores que tiene que afrontar la compleja tarea de impartir español a alumnos que lo tiene como lengua familiar. Para poder encontrar una metodología apropiada, es necesario tener en cuenta cuatro temas centrales: 1) la identidad social del bilingüe y las diferentes etiquetas que se usan en el mundo académico para identificarlos, 2) la amplia gama de niveles de competencia lingüística de los aprendices de español como lengua de herencia, 3) las habilidades de los aprendices en el español académico y 4) la medición de la competencia del bilingüe en general.

Palabras claves: aprendices de lengua de herencia, competencia lingüística, habilidades académicas y bilingües.

\section{INTRODUCTION}

Although the idea of teaching Spanish to Heritage speakers ${ }^{1}$ (HS) dates back to the 1930 s, it was in the 1960s that it gathered strength, mainly among Chicano activists who, inspired by the Civil Rights Movement (and el movimiento chicano), felt that the instruction

${ }^{1}$ I will use the terms Heritage learner, Heritage speaker, Heritage student and Bilingual speaker when referring to US Latino / Hispanic or Spanish speakers who have Spanish as a Family or Heritage language. 
of Spanish was the best means of preserving and maintaining their ancestral language for future generations (Valdés, 1981). In subsequent years, language educators raised important concerns with respect to (1) the lack of suitable textbooks and materials, (2) whether to accept the many varieties of Spanish used by HS or teach the «norma culta», (3) the necessity of training those who would teach Spanish for Native Speakers (SNS) (Roca, 2000), (4) how to design an effective curriculum, and (5) how to best assess language proficiency (Valdés, 1995; Roca, 1997).

In light of the mounting research on the theory and practice of teaching Spanish as a Heritage language, we must examine four key issues: (1) the social identity of Heritage speakers and the use of labels in academia, (2) the wide range of language proficiency among Heritage language learners, (3) the «undeveloped» academic register of Heritage learners, and (4) the all-important measurement of bilingual skills. In the first part of this article, I examine each of these issues from different pedagogical perspectives, and in the second part, I offer conclusions.

\section{THE SOCIAL IDENTITY OF THE BILINGUAL SPEAKER AND THE USE OF LABELS IN ACADEMIA}

Language and the social construction of identity have been the subject of research in linguistics, pedagogy, social psychology, and anthropology, among other disciplines. Language use and attitude, socio-economic status, social networks, out- and in-group membership, family origin, citizenship, and birthplace can all shape one's social identity. Individuals may identify with the language they speak or they may reject, especially it if it is stigmatized by those who hold economic, social and political power in the community (Bourdieu, 1994). As Bourdieu observed, those who speak the non-standard variety of a language believe that the acquisition of the prestige variety will gain them access to the linguistic market.

The Bilingual speaker's social identity is established by many factors which, in turn, play an important role in identity labelling. For instance, the term Hispano broadly refers to all members of the Spanish-speaking community in the United States. The more regional terms Chicano, Tex-Mex, and Pocho, on the other hand, may be rejected because of their traditional association with poverty, ruralness, unemployment, Spanglish, and unskilled people (Galindo, 1996; Sánchez, 1994). Latino is another term generally used to refer to someone from Latin America. But it may also refer to anyone who uses Spanish in public or private settings. Ultimately, social identity can be defined in terms of country of origin, such as Colombian-American, Mexican-American, and Cuban-American.

Although the term Hispanic may refer to those who speak Spanish as their dominant language, there are many who oppose the label because not all Hispanics speak the language at home or elsewhere. Zentella (1997) revealed in her study of New York Puerto Ricans that being Hispanic does not necessarily indicate Spanish-speaking, and that to be Puerto Rican one needS not be born in Puerto Rico. Not only is language labelling problematic, but so are terms like Puerto Rican, Mexican, or Chicano to refer to Spanish speakers in the United States. In fact, those who consider themselves 'native speakers' 
may mock third and fourth generation speakers who label themselves as Spanish speakers. Thus, negative remarks may perpetuate low self-esteem among the less proficient bilinguals, and the fact that they often speak a non-standard variety may inflate such criticism. In this regard, Carreira (2000) claims that «the derisive attitudes about U.S. Spanish that prevail in this country, as well as abroad, represent a particularly serious obstacle to the goal of enhancing students' linguistic self-esteem» (436). She goes on to say that relatives, classmates, as well as teachers may contribute to the downgrading of a student's linguistic abilities. Villa and Villa (1998) claim that in-group membership may be determined by linguistic differences. For instance, if a speaker's standard variety is deemed to be more correct, he or she may identify with that language variety.

Self-identity appears to have implications for Heritage language programs. Villa and Villa state that «individuals who are of Spanish-speaking origin but who have lost the language to one degree or another may choose a label based on factors other than physical characteristics» (1998: 508). Their research reveals that Spanish language usage correlates with country of origin as a self-identifying label. On the other hand, third and fourth generation speakers use labels that establish a distinct in-country group identity, such as Chicano, Hispanic, Mexican-American, and Spanish. One of their conclusions is that self-identification has major consequences on student enrolment in Heritage language courses. Students may enrol in a non-native Spanish course because they perceive that they are not 'native speakers'. In view of this, Lynch (2003) claims that language placement "should be addressed in light of students' functional abilities in Spanish, independently of students' self-reports and administrators' classificatory debates about who is more 'bilingual' or more 'native'» (30). In academia, SNS (Spanish for Native Speakers) has been the conventional term used to label courses designated for Spanish Heritage speakers. Some scholars have abandoned the term SNS for SHL (Spanish as Heritage language) (Valdés, 2001; Lynch, 2003; Carreira, 2004).

It is not an easy task to define the term 'native-speaker' or nativeness (Andreou and Galantomos, 2009). It is crucial to bear in mind that the notion of 'native' speaker may be intrinsically linked to that of a 'fluent' speaker. The concept of a fluent speaker seems to be best defined and recognized by a particular speech community because speakers' nativeness is considered to be within the boundaries of the speech community. However, this view may be flawed because there is no such thing as a homogenous speech community, and because nativeness can vary from one individual to another within the same community (Romaine, 1989; Paradis, 1998; Andreou \& Galantomos, 2009). For instance, Paradis (1998: 205) argues that «one is not a native speaker of a language but of a given sociolect of a particular dialect.»

As Lynch (2003) points out, the concepts of 'native', 'heritage', and 'bilingual' need to be considered when recruiting Spanish-speaking students for HL courses. The best approach is for instructors to demystify the construct of native speaker by being sensitive when dealing with it in the classroom. The use of the label native speaker by many teachers and administrators overlooks the complex circumstances of many Spanish Heritage speakers in the United States. In the following section, I will outline some of the mitigating factors that can shed light on the correlation between a bilingual speaker's proficiency level and his or her circumstances. This will enable us to better understand the many labels of self-identity used by Heritage speakers. 


\section{The language PROFiciency LeVels OF HeRitage SPEAKERS}

Guadalupe Valdés $(1995,1997)$ outlines eight different types of Heritage learners, classifying each group according to their Spanish and English academic skills, as well as Spanish language proficiency. The sociolinguistic variables taken into account are the speakers' generation (newly arrived, second, and third generation), formal instruction both in English and Spanish, and instruction in a prestige variety of Spanish. What can be inferred from Valdés' taxonomy is that language proficiency and academic skills can vary greatly within each group. For instance, good academic skills in Spanish do not always yield fluency in a prestige variety, and vice versa. Hence, the common assumption that academic skills in Spanish correlate with fluency in a prestige variety of Spanish does not hold. Such discrepancies between academic skills and language proficiency levels represent enormous challenges for HL teachers. One important conclusion is that each type of language learner differs with respect to language goals and needs. For example, Spanish speakers newly arrived to the United States may seek language maintenance, continuation or expansion of language competence, and acquisition of a prestige variety. Conversely, the needs of second and third generation speakers would entail expansion of the bilingual range, transfer of literacy skills from English to Spanish, as well as acquisition of a prestige variety (Valdés, 1995: 307). An important question, then, especially for teachers and administrators of HL programs, is what mitigating factors can justify the wide range of Spanish language proficiency levels among HL students. I believe those factors to be language use and attitudes, 'imposed' assimilation into mainstream society, and socio-economic conditions.

Language prestige can have such an effect on language attitudes that it can inspire minority language groups to maintain or to abandon their ancestral language. In multilingual societies such as the United States, it becomes a question of language power and ideology, where languages other than English are judged by some as a threat that results in the encroachment of the less prestigious language upon the more prestigious one (Milroy, 2001). Then, the important concern becomes whether or not minority languages are to co-exist with English, and how the bilingualism of those who possess a family language other than English can be maintained. Schooling that supports the maintenance of the home language will help students to maintain it while they acquire the majority language (Shannon, 1998; Freeman, 1999; Cummins, 2001; de Jong, 2002). Yet, the maintenance of bilingual education programs has become a contentious issue in areas where there is a significant presence of Hispanics, such as in the southwest part of the United States. For instance, Proposition 227 became the alternative in California to end bilingual education. According to Stritikus (2002), Proposition 227, known as the Englishonly law, has affected many linguistically and culturally diverse students who are pressured to give up their family language so as to better assimilate into mainstream society. Likewise, Cummins (2001) considers it as a deliberative coercive force that doesn't support biliteracy among Latino students in the Unites States. Cummins (2001) states also that many opponents accept as true that bilingual education involves teaching literacy in the Heritage language in detriment of the majority language.

It is increasingly evident that minority language students with low socio-economic status will have difficulty maintaining their bilingual skills if they feel that in order to 
succeed in American society; they must give up their family language (Tse, 2001; Winsler, 1999). On the other hand, families with a relatively high socio-economic status may succeed in encouraging bilingualism among younger generations simply because they have the resources to maintain it (Tuominen, 1999; Wei 2002). Despite the fact that bilingual students do not have a choice but to pursue their education in a monolingual school system, many succeed in developing their bilingual skills. One reason that some parents support Heritage language classes outside school hours, for example, is to ensure that their children do not lose their family language. There are cases in which parents will use only the family language at home with their children and English outside the home (Fishman et.al, 1971; Grosjean, 1982). Some may send their children abroad for the opportunity to practice the family language with relatives (Milroy, 2001).

The exposure of Heritage speakers to the family language is often limited to the home domain (Valdés, 1998; Carreira, 2000; Wei, 2002). At the same time, once children begin their formal education in the majority language, they begin to relinquish the use of the Heritage language, and embrace the majority language as the primary mode of communication beyond the home (Hernández-Chávez, 1993; Hidalgo, 1993). In the Southwest, for instance, if parents have a strong desire to assimilate, English will enter the child's life through schooling and «upon the insistence, for example, of teachers and other authority figures that they discourage the use of Spanish not only in the school but also at home, and that they encourage the use of English» (Hernández-Chávez, 1993: 61). The schooling that takes place in English is, therefore, one of the factors that gives rise to the different levels of language proficiency in the HL classroom (Aparicio, 1983: 233). It would be unreasonable to expect HL students to have acquired the formal registers of the Spanish language upon entering college. We must take into account that laws such as Proposition 227, and the like, do not leave a choice to some HL speakers but to rapidly acquire English. To make matters worse, some parents consciously support the abandonment of the ancestral language because they firmly believe that Spanish is an obstacle to social and economic success.

Attitude toward one's own language variety is another factor that stems from the complex circumstances of HL students. Some scholars observed that Chicano students tend to perceive their own Spanish as 'bad' or 'incorrect' (Villa, 1996; Valdés, 1981, 1998; Hernández-Chávez and Bernal-Enríquez, 2003). On this subject, Valdés (1981: 10) notes that the acquisition of the prestige variety of a language does not imply eradicating the non-standard variety. She claims that teachers have a tendency to 'correct' their bilingual students when they speak. Likewise, Bernal-Enríquez and Hernández-Chávez (2003: 97) claim that «ciertos sectores de la sociedad hispanoparlante, en particular los educadores, consideran las hablas regionales como un español degenerado, inválido, y corrupto que no tiene lugar en el discurso gentil, menos en el aula de clase».

Teachers that follow the 'norma culta' attempt to suppress a particular variety of Spanish by exposing students to the grammar endorsed by the Real Academia Española (Sánchez 1981: 92). García-Moya, who regards as 'puristas' those who follow the prescriptive approach, states that the main goal is «to eradicate the dialect or, at least, to transform dialect speakers into speakers of standard Spanish dialect» (1981: 59). As a consequence, those who foster the teaching of «el español normativo» will have a negative impact on HL students. Floyd (1981) insists that a well-informed teacher can instruct students into linguistic realities and foster positive attitudes toward their own variety. 
Therefore, the teaching of Spanish to HL students requires teachers to be linguistically aware and well-informed, and to have knowledge of sociolinguistics. It is important to note that teachers of HL students may not necessarily be 'native speakers', or be from a Spanish-speaking country, or have had a formal college education in Spanish. In fact, Aparicio (1983: 234) claims that «it is self-defeating to select an individual from Spain or from a South America country to teach S-S courses if said teachers considers the Spanish used by the students as 'vulgar', and if the same teacher would try to change students' use of Spanish to an Argentinean, Colombian or Peninsular mode.»

Many scholars have stressed the importance of classroom activities that prepare students to become aware of language variation in the United States (García-Moya, 1981; Merino et. al, 1993; Rodríguez, 1997; Carreira, 2000, 2003; Lynch, 2003; Carrasco and Riegelhaupt, 2003). According to Lynch's 'variability principle' (2003: 37), knowledge of language variability is an essential asset for teachers as they strive to increase the HL learners' awareness of dialect and register variation. Similarly, Carrasco and Riegelhaupt (2003) propose the META approach, which involves data collection and analysis of the students' language acquisition process. This approach embraces the concept of 'metalinguistic knowledge' that seeks to increase the students' awareness of language by promoting sensitivity to different dialects. García-Moya (1981) believes that HL students should learn that they can alternate between their dialect and a more standard Spanish according to their needs, just as native speakers do when interacting in different situations.

HL students bring to the classroom their own 'linguistic baggage'. If teachers don't address these issues, they may endlessly remark 'no se dice así'. It is critical, therefore, that HL classroom activities focus on issues such as dialectal variation, which can empower Heritage language students to communicate with a diverse Spanish-speaking population. Rodríguez (1997) has highlighted the use of encuestas sociolingüisticas, an ethnographic approach that helps students get acquainted with lexical variation within their community, home, and school environment. Likewise, the language recontact principle (Lynch 2003: 39) underscores the students' need to develop social networks through community service projects, study abroad programs, business internships, and schools and organizations that deal with Spanish speakers.

Another factor we must consider, aside from linguistic insecurity, language use and attitudes are the sociological and cultural differences among Spanish Heritage speakers. As Roca and Colombi (2003: 4-5) indicate, HL teachers ought to take into account the attitudinal and socio-historical and economic factors affecting students. US Spanish speakers have undergone a wide variety of sociological experiences depending on their regional setting in the United States. Consequently, instruction and activities need to be adapted to those situations. Carreira (2003: 68) points that «SNS instruction must be regionally anchored. Pedagogical goals and materials that may be appropriate in Miami, for example, may be entirely out of place in the Southwest. Therefore, it is essential for SNS teachers to know the student population and local Hispanic communities they are dealing with.»

The complex and multiple circumstances that define Spanish Heritage students in the United States can be summarized as follows: (a) Spanish may be the first language of many students before schooling, but English tends to be the first language acquired in school, (b) society often holds negative attitudes toward certain varieties of Spanish, (c) 
there are many standard varieties of Spanish, (f) some Heritage speakers may occasionally resort to English when interacting in Spanish (e.g., code-switching), (g) the HL students' use of Spanish is frequently limited to the family domain, and (h) their academic ability in Spanish is limited. As many experts point out, HL instructional goals should include (a) learning about the Spanish language and culture with a sense of pride, (b) increasing awareness of the different varieties of Spanish, and (c) empowering students by highlighting the career, cultural, and social benefits of being bilingual in the United States.

\section{The «Undeveloped» aCademic Register of U.S. Heritage language LEARNERS}

Many HL learners stress that one of their main objectives in signing up for Spanish Heritage language courses is to acquire competence in their written and oral abilities. They recognize the importance of developing these skills for academic and professional success. Access to the oral academic discourse not only makes it possible for students to deliver presentations in front of a class or to answer questions in the appropriate register, but it also enables them to enter the world of academia, for instance (Boxer, 2002; Achugar, 2003). Many HL students enter college with a good grasp of how English formal registers are achieved. Upon taking HL courses, however, they become conscious that they are not able to use Spanish as a vehicle for expressing concepts, theories, and abstract thoughts. This begs the question: what are the factors that result in the undeveloped academic register among HL students?

The mitigating factor of the so-called 'undeveloped' academic register (Valdés and Geoffrion-Vinci, 1998) rests on the fact that many of these students have attained their primary and secondary education in English. Consequently, they did not have the opportunity to develop their heritage language skills. Their Spanish language repertoire has been acquired mainly through interaction with family and friends. Therefore, when HL students tend to write essays or deliver class presentations, their Spanish morphosyntactic, lexical, and semantic-pragmatic choices are likely to echo their 'informal' register (Valdés, 1998; Fairclough and Mrak, 2003; Achugar, 2003). Taking into account the distinction that Cummins $(1980,1983)$ delineates between BICS (Basic Interpersonal Communication Skills) and CALP (Cognitive Academic Language Proficiency), we can argue that HL students have developed the interpersonal communication skills straightforwardly because BICS is cognitively undemanding. But, when in school, HL students seek to develop language proficiency at the academic level; that is to say: literacy-related skills, which are more demanding than BICS.

Many scholars suggest that instruction that concentrates on developing the academic register of Heritage speakers should not lead to the eradication of their vernacular mode (Villa, 1996; Valdés, 1981, 1998; Bernal-Enríquez and Hernández-Chávez 2003); rather it should focus on content-based and genre instruction (Achugar, 2003), on developing writing strategies (Schwartz, 2003), on a functional approach (Colombi 1997, 2000, 2003), and on a cultural and critical literacy approach (Cummins, 2001). Traditionally, teachers of HL have approached the instruction of academic writing from a prescriptive standpoint. 
They believed that students need to reject their non-standard variety. Valdés claims that HL teachers should endorse «development and enrichment of language skills within existing dialects» (1981: 19).

If Spanish HL students need to acquire a given academic register, it is important to properly identify and define this register. In her comparative research on the oral academic register between Mexican bilinguals and monolinguals, Valdés (1998) states that the limited lexical range, the few strategies for managing academic instructions, the restricted resources for characterization of one's or another's contributions to the discussion, and the difficulty of presenting oneself as competent and knowledgeable are some of the characteristics that make bilinguals «appear to be young, unsophisticated, and sometimes even inarticulate» (494). She concludes, for instance, that bilingual speakers tend to use more coordinate sentences than embedded clauses: «el lenguaje coloquial, familiar se caracteriza por su estilo relativamente telegráfico y el predominio de oraciones coordinadas, frases incompletas, estructuras modificadas simples, etc.» (Solé, 1981: 28)

Fairclough and Mrak (2003:209) compare the oral production of bilinguals who have had formal instruction in Spanish with those who have not. Their results reveal that the major differences are at the lexical level. For this reason, many teachers and scholars have advocated for activities that make students aware of lexical variations, such as oral presentations, and tape-recordings of television and radio programs. With respect to the written mode, Colombi (2003) claims that a systematic functional linguistic approach offers a great opportunity to aid HL students to develop their academic register. This approach attempts to develop the students' awareness on how writing (the text) is linked to the context (social and otherwise). By doing so, students can assess their academic register in terms of linguistic features such as lexical density and syntactic complexity. This approach can lead students to gain an awareness of how form and meaning are constructed during the writing process. As Colombi puts it so eloquently, «este marco teórico hace explícitas las características discursiva-semánticas y léxico-gramaticales de los textos permitiéndoles a los estudiantes un conocimiento más claro y accesible que rompe con los mitos acerca de la dificultad de aprender a escribir» (Colombi, 2003: 91).

Cummins (2001) call for a cultural and critical literacy approach that can empower students and teachers in the classroom and beyond. Cummins argues for Ada's framework that combines three phases: 1) a descriptive phase which focuses on textual information, 2) a personal interpretative phase which helps students to relate textual information to students' personal experiences, 3) a critical analysis phase which will helps the students to engage in more abstract thinking, and 4) a creative action phase which can empower students to resolve and change societal challenges.

Schwartz (2003) and Acevedo (2003) emphasize the importance of teaching HL students how to plan, compose, and revise their written compositions. Schwartz recommends the practice of developing writing strategies and placing emphasis on meaning when revising. She observes that lack of vocabulary is a major concern for many heritage students, along with familiarity with paraphrasing techniques. She suggests that content and meaning be their first priority when writing, and that spelling and grammatical features be stressed only during the editing process. The HL student's written academic register may encompass a wide variety of activities such as controlled compositions, selfediting exercises, written dialogues in standard Spanish and in the student's dialect, 
dialogue transcriptions, free composition, translations, creative writing, student-teacher dialogue, and peer writing (Alonso, 1983: 330-340). Fairclough and Mrak (2003) point out that the common 'errors' found in oral discourse are omission of obligatory determinants, gender agreement, and the order of grammatical categories within clauses. Teschner (1981) examines the patterns of 'errors' in first-year compositions by HL students enrolled in HL courses at the University of Texas in El Paso. He observes some commonalities such as the absence or unnecessary presence of the written accent, confusion of graphemes representing identical phonemes $(\mathrm{b} / \mathrm{v}, \mathrm{c} / \mathrm{s} / \mathrm{z}, \mathrm{qu} / \mathrm{c})$, addition or deletion of $/ \mathrm{s} /$, confusion between minimal pair infinitives (haber/ver, hacer/ser), absence of obligatory prepositions, and gender / number disagreement.

There is a clear consensus among scholars that many HL students have not developed the required 'academic register' due to the lack of opportunity for formal study of the family language in primary and secondary schools. HL teachers simply cannot expect HL students to handle formal registers despite the fact that many speak the heritage language with ease. The greatest challenges take place in classrooms that consist of newly arrived Spanish speakers who have had some formal education in Spanish at one extreme, as well as U.S. Spanish speakers with a low-level academic register at the other. It is not surprising, therefore, to find in HL classrooms great discrepancies in proficiency levels. While there is general agreement that HL students need to develop both the formal and informal varieties of Spanish, the thorny task is assessing and distinguishing between their formal and informal Spanish register. In order words, how can we assess their bilingual range, defined by Valdés (1995) as «the continuum of linguistic abilities and communicative strategies that an individual may access in one or the other of his or her two languages at a specific moment, for a particular purpose, in a particular setting, with particular interlocutors» (316).

The most crucial task is how to effectively measure HL students' bilingual range so that they can enrol in the appropriate course. The measurement of the bilingual range and linguistic competencies is in and of itself a contentious issue. The following section presents an overview of the latest research on instruments used to measure HL students' Spanish proficiency. As will be discussed, the major debate revolves around the theoretical and practical ramifications of using the ACTFL Proficiency Guidelines to measure the language proficiency level of Heritage students.

\section{Assessment and measurement of Bilingual SKills}

Much of the debate regarding the measurement of HL students' language proficiency has been linked to the validity of placement tests such as the OPI (Oral Proficiency Interview) offered by ACTFL (American Council of the Teaching of Foreign Languages). In 1968 FSI (Foreign Language Service), DLI (Defence Language Institute), and CSC (Civil Service Commission) set in motion several policies with the aim of defining the levels of language proficiency of those learning or acquiring foreign languages (Barkin, 1981). Barkin does not confirm that the FSI was used to measure the language proficiency of bilingual speakers. Instead, she reports the use of other placement tests such as the one designed by Hernández-Chávez and Dulay (1975, in Barkin 1981), known as the Bilingual 
Syntax Measure (BSM), which assesses proficiency at the syntax level. A year later, in 1976, Sánchez criticized the BSM because it did not take into consideration the students' sociolinguistic profiles such as language variants, code switching practices, and speech functions. Meanwhile, Barkin and associates had developed their own placement test for bilingual teachers at Arizona University in 1975. This instrument, however, also overlooked the phenomenon of language variation, and was designed to measure grammatical accuracy.

In 1979, the FSI served as a basis for the creation of the ACTFL Provisional Proficiency Guidelines. Yet again, the major concern for many scholars and teachers was to determine if those guidelines could be used to evaluate a HL student's language proficiency. As Valdés (1989) stressed, it must be clear that ACTFL's objective is to measure the language proficiency of foreign language students, not to evaluate the language proficiency of those students who have Spanish as a family language. Hence, language variation among the many varieties of Spanish is not assumed. ACTFL clearly intended to measure language proficiency in the 'norma culta' (Valdés, 1989: 399). Valdés cites Lantof and Frawley (1985) who explain that «the guidelines were derived from an implicit notion of the mean linguistic behavior of an ideal speaker» (394).

Valdés (1989) states that «ACTFL ignores regional and social varieties of Spanish. Then [...] will testers tend to see dialect differences as patterned errors?» (400). Likewise, Barnwell (1993) claims that ACTFL cannot predict what native speakers will do. He adds that there is an elitist point of view with regard to language proficiency, «the test measures how non-natives perform, but they don't measure how native speakers perform» (205). Conversely, Alonso (1997) states that ACTFL guidelines are more likely to assess the monolingual level of competencies, than the bilingual repertoire, which is more complex. What is clear is that ACTFL guidelines presuppose what 'native speakers' do with the language. Valdés and Figueroa (1994) raise important questions concerning the extent to which we measure native-speaker ability or second language proficiency. Ultimately, the main dilemma revolves around the notion of 'native speaker', fluent speaker, or ideal speaker (Chomsky, 1972²).

It should be stressed that the ACTFL Guidelines were developed to test students of foreign languages and not HL students. Therefore, HL scholars, administrators, and educators must move beyond ACTFL, and seek other ways to measure HL students' language proficiency. Many suggestions have been put forward. Valdés and Figueroa (1994) suggest two approaches for measuring language proficiency. One involves measuring the performance of bilingual individuals across a wide variety of tasks, contexts, setting, modalities, and functions. The other involves comparing their performance with the performance of monolingual speakers on the same set of tasks. Measuring bilingual language proficiency is not a simple undertaking. If we used Cummins' $(1980,1983)$ taxonomy of BICS and CALP, then it may be possible to argue that most language proficiency tests, such as ACTFL, are designed to measure CALP, which is contextreduced if compared to BICS, which is context-based.

${ }^{2}$ Chomsky (1972) defines a native speaker as «a fluent native speaker's knowledge of grammaticality» (115-116). Chomsky constrained the knowledge of competence, to knowledge of grammar. 
I claim that a more accurate assessment would have to include a combination of direct and indirect measures such as language background questionnaires, self-rating scales, language samples, etc. Valdés and Figueroa (1994: 40) conclude that

In deciding what need to be measured one has the following choices: (a) one can decide to view the bilingual speakers as native speakers of both languages, (b) one can decide to view the bilingual speakers as native speakers of one language and second language speakers of the other, or (3) one can decide to view the bilingual speakers as native speakers of neither of the two languages.

\section{Concluding remarks}

yo no creo que lo voy a perder porque I never really lost.it... Richard

yo soy una mujer inteligente, me gusta usar palabras inteligentes y tener que usar palabras tan simples todo el tiempo me hace sentir como una tonta

Sussy

Richard, 19 years old, and Sussy, 21years old, were Spanish Heritage language learners at the University of Florida.

Earlier on, I pointed out that the teaching of Heritage languages can help to maintain and preserve a minority group's ancestral language. With respect to Spanish in the United States, several factors come into play. The demographic growth of Spanish speakers, the fostering of positive attitudes toward Hispanic culture and the many varieties of Spanish, and the visibility of Spanish in public spheres of interactions (business, education, music, film, and mass media) can play a major role in the maintenance of the Spanish language among successive generations. The validation and promotion of Spanish among U.S. Hispanics can be fostered through education, particularly HL instruction. Concurrently, HL instruction must be sound with respect to the corresponding research on the subject. It is widely accepted that HL practice needs to resolve three interrelated issues associated with the complex circumstances of HL students: (1) social identity recognition; (2) the critical need of developing formal registers in Spanish, such as business and academic; and (3) the assessment of language proficiency.

While labels such as Hispanic, Latino, Mexican-American or Nuyorican do not equate language proficiency per se (Zentella 1997), they do play an important role in reinforcing HL students' self-identity. These labels must be recognized and accepted by all Spanish-speaking groups because culture and language are interconnected. What connects a U.S.-born Spanish speaker to other Spanish-speaking groups is language and culture, in a global sense. The recognition of one's label, therefore, is critical if the objective is to nurture language maintenance. HL classrooms can help to validate and promote self-identification and a sense of pride. As the acceptance of diversity fosters self-esteem, it also empowers students to develop their Spanish language skills.

The other piece of the question touches upon the concept of 'native speaker', as some scholars point out (Hidalgo, 1993; Vila, 1996; Valdés 1989), or 'the trap of the nevernative-speaker' (Lynch, 2003: 32). Villa (1996) observes that the use of the term 'native 
speaker' may discourage HL students from enrolling in HL courses because so many of them feel that they are not native speakers. This where the instructor can play a crucial role; first, by dealing with this particular label and discussing it openly in the classroom; and secondly, by pointing out that the term 'native speaker' «is largely in the eyes of the beholder» (Valdés 1998: 157). Cook (1999 in Lynch 2003: 33) claims that we ought to make HL students aware that «they are successful multi-competent speakers, not failed native speakers».

HL educators must acknowledge that the self-identifying labels employed by many HL students can reveal that language use and attitude play an important role in shaping the social identity of bilingual speakers. They must also be aware that students' perception of their Spanish variety is due to a lack of acknowledgement of the different ones spoken in the U.S. For instance, Hernández-Cháves (2003) states that Chicano Spanish has been stigmatised not only among 'puristas' but also within the Chicano community that perceives their dialect as corrupted and improper. Those who deem the Spanish spoken in the U.S. as 'bad' tend to ignore the HL student's sociolinguistic background. For example, some of the morpho-syntactic features found among second and third generation speakers are due to incomplete acquisition of Spanish or internal language changes (Silva-Corvalán, 2003).

As I have pointed out, language attitude among Hispanic speakers can also be linked to socio-economic conditions. For instance, some families believe that the acquisition of English is vital for economic and social success and, therefore, may consciously discontinue using the ancestral language at home. As a consequence, many HL students are placed in mainstream schools for the purpose of rapid immersion in the majority language. While these students do succeed in achieving competency in English, they do not typically receive formal education in Spanish. Subsequently, upon entering college, they feel the pressure to develop their academic register in Spanish, especially if they want to major in it. Formal education in Spanish then becomes a challenging task, not only for the students but for HL instructors as well. Those who have not been trained in the teaching of Spanish as a Heritage language believe that grammar drills and mechanical adjustments are the best approach. Scholars have suggested otherwise, i.e., that content-based learning, within which grammar is at the service of communication, is a more effective method (Roca, 1997; Lynch, 2003).

Finally, it bears reiterating the importance of proper assessment of proficiency levels. It is clear that the ACTFL Guidelines have many drawbacks primarily because they fail to take into account the many varieties of Spanish. The Heritage Language Profession is essentially trapped in its unremitting efforts to use the ACTFL instrument (a tool based on the notion of 'ideal-native-fluent speaker') to measure Heritage language proficiency. It would be more productive to rely on a combination of direct and indirect measures.

There is no doubt that HL scholars have made tremendous advancements in their research on the pedagogical implications of teaching language to HL students. Many of their theories have resulted in enhancing the instruction of Spanish as a Heritage language, and have helped educators to better understand the HL speakers' sociolinguistic profile. I propose that we take it a step further, and that teachers take it upon themselves to become researchers in action in their own classrooms. Collaboration between scholars and teachers can be mutually beneficial in stimulating research on so many unresolved 
issues. The successful resolution of those issues can help to transform HL students into «multi-competent speakers» (Cook, 1999).

\section{REFERENCES}

Acevedo, R. (2003). «Navegando a través del registro formal», in A. Roca and C. Colombi (eds.), Mi lengua: Spanish as a heritage language in the United States, research and practice. Washington, D.C.: Georgetown University Press, 257-268.

Achugar, M. (2003). «Academic registers in Spanish in the U.S.», in A. Roca and C. Colombi (eds.), Mi lengua: Spanish as a heritage language in the United States, research and practice. Washington, D.C.: Georgetown University Press, 96-119.

Alonso, E. (1997). «La evaluación de la actuación oral de los hispanoparlantes bilingües mediante las directrices de ACTFL», in Hispania, 80: 328-341.

Andreou, G. and Galantomos, I. (2009). «The Native Speaker Ideal in Foreign Language Teaching», in Electronic Journal of Foreign Language Teaching, 6, 2: 200-208, available from http:/ /eflt.nus.edu.sg/main.htm, accessed April, 2010.

Aparicio, F. (1983). «Teaching Spanish to the native speaker at the college level», in Hispania, 66: 232-238.

Barkin, F. (1981). «Evaluating linguistic proficiency: the case of teachers in bilingual programs», in G. Valdés, A. Lozano and R. García-Moya (eds.), Teaching Spanish to the Hispanic Bilingual in the United States: Issues, Aims, and Methods. New York: Teachers College Press, 215-231.

Barnwell, D. (1993). «Oral proficiency testing and the bilingual speaker», in A. Roca and J. Lipski (eds.), Spanish in the United States: linguistic contact and diversity. Berlin / New York: Mouton de Gruyter, 199-210.

Boxer, D. (2002). Applying Sociolinguistic: Domains and face-to-face interaction. Amsterdam/ Philadelphia: John Benjamins Publishers.

Bourdieu, P. (1999). «Language and symbolic power», in N. Coupland and A. Jaworski (eds.), The Discourse Reader. London / New York: Rutledge, 502-513.

Carrasco, R. and Riegelhaupt, F. (2003). «META: A model for the continued acquisition of Spanish by Spanish / English bilinguals in the United States», in A. Roca and C. Colombi (eds.), Mi lengua: Spanish as a heritage language in the United States, research and practice. Washington, D.C.: Georgetown University Press, 170-197.

Carreira, M. (2000). «Validating and Promoting Spanish in the United States: Lessons from Linguistic Science», in Bilingual Research Journal, 24, 4: 423-442.

Carreira, M. (2003). «Profiles of SNS students in the twenty-first century», in A. Roca and C. Colombi (eds.), Mi lengua: Spanish as a heritage language in the United States, research and practice.Washington, D.C.: Georgetown University Press, 51-77.

Carreira, M. (2004). «Seeking explanatory adequacy: A dual approach to understanding the term heritage language learner», in Heritage LanguagJournal, 2, 1, available from http:// www.heritagelanguages.org, accessed September, 2008.

Colombi, C. (1997). «Perfil del discurso escrito en textos de hispanohablante: teoría y práctica», in C. Colombi and F. Alarcón (eds.), La enseñanza del español a hispanohablantes: Praxis y teoría. Boston, Massachusetts: Houghton Mifflin, 175-189. 
Colombi, C. (2000). «En vías del desarrollo del lenguaje académico en español en hablantes nativos de español en los Estados Unidos», in A. Roca (ed.) Research on Spanish in the United States: linguistic issues and challenges. Somerville, Massachusetts: Cascadilla Press, 296309.

Colombi, C. (2003). «Un enfoque funcional para la enseñanza del ensayo expositivo», in A. Roca and C. Colombi (eds.), Mi lengua: Spanish as a heritage language in the United States, research and practice.Washington, D.C.: Georgetown University Press, 78-96.

Chomsky, N. (2006). Language and Mind. Cambridge: Cambridge University Press.

Cook, V. (1999). «Going beyond the native speaker in language teaching», in TESOL Quarterly, 33: 185-209.

Cummins, J. (1980). «The entry and exit fallacy in bilingual education», in NABE Journal 4, 2560.

Cummins, J. (1983). «Language proficiency and academic achievement», in J. W. Oller (ed.), Current Issues in Language: Testing Research. Rowley, Mass.: Newbury House, 108-130.

Cummins, J. (2001). «Empowering Minority students: a framework of intervention», in C. Baker and N. Hornberger (eds.), An Introductory Reader of the writing of Jim Cummins. Clevedon, England: Multilingual Matters, 175-194.

Cummins, J. (2001). «Heritage Language Teaching in Canadian Schools», in C. Baker and N. Hornberger (eds.), An Introductory Reader of the writing of Jim Cummins. Clevedon, England: Multilingual Matters, 257-252.

Cummins, J. (2001). «Empowerment through biliteracy», in C. Baker and N. Hornberger (eds.), An Introductory Reader of the writing of Jim Cummins. Clevedon, England: Multilingual Matters, 258-284.

de Jong, E. (2002). «Effective Bilingual Education: From theory to academic achievement in a twoway bilingual program», in Bilingual Research Journal, 26, 1: 65-84.

Fairclough, M. and Mrak, A. (2003). «La enseña del español a los hispanohablantes bilingües», in A. Roca and C. Colombi (eds.), Mi lengua: Spanish as a heritage language in the United States, research and practice. Washington, D.C.: Georgetown University Press, 198-212.

Floyd, M. (1981). «Language variation in Southwest Spanish and its relation to pedagogical issues», in G. Valdés, A. Lozano and R. García-Moya (eds.), Teaching Spanish to the Hispanic Bilingual in the United States: Issues, Aims, and Methods. New York: Teachers College Press, 30-45.

Fishman, J., Cooper, R. and Newman, R. (1971). Bilingualism in the Barrio. Bloomington, Indiana: Indiana University Press.

Freeman, R. (1998). Bilingual Education and Social Change. Philadelphia: Multilingual Matters.

Galindo, L. (1996). «Language use and language attitudes: a study of border women», in The Bilingual Review/La revista bilingüe, 21, 1: 5-17.

García-Moya, R. (1981). «Teaching Spanish to Spanish speakers: some considerations for the preparation of teachers», in G. Valdés, A. Lozano and R. García-Moya (eds.), Teaching Spanish to the Hispanic Bilingual in the United States: Issues, Aims, and Methods. New York: Teachers College Press, 59-70.

Grosjean, F. (1982). Life with Two Languages: An introduction to Bilingualism. Cambridge, Massachusetts: Harvard University Press.

Hernández-Chávez, E., Cohen, A. and Beltramo, A. (eds.) (1975). El lenguaje de los chicanos. Arlington, Virginia: Centre for Applied Linguistics.

Hernández-Chávez, E. (1993). «Native language loss and its implications for revitalization of Spanish in Chicano communities», in B. Merino, H. Trueba and F. Samaniego (eds.), 
Language and culture in learning: Teaching Spanish to Native Speakers of Spanish. Washington. D.C: Falmer Press / Taylor \& Francis, 58-74.

Hernández-Chávez, E. and Bernal-Enríquez, Y. (2003). «La enseñanza del español en Nuevo México», in A. Roca and C. Colombi (eds.), Mi lengua: Spanish as a heritage language in the United States, research and practice. Washington, D.C.: Georgetown University Press, 96-119.

Hidalgo, M. (1993). «The teaching of Spanish to bilingual Spanish-speakers: a 'problem' of inequality», in B. Merino, H. Trueba and F. Samaniego (eds.), Language and culture in learning: Teaching Spanish to Native Speakers of Spanish. Washington. D.C: Falmer Press / Taylor \& Francis, 82-93.

Lantof, J. and Frawley, W. (1985). «Oral proficiency testing: a critical analysis», in Modern Language Journal, 69: 227-45.

Lynch, A. (2003). «Toward a theory of heritage language acquisition: Spanish in the United States», in A. Roca and C. Colombi (eds.), Mi lengua: Spanish as a heritage language in the United States, research and practice. Washington, D.C.: Georgetown University Press, 2550.

Merino, B., Trueba, H. and Samaniego, F. (eds.) (1993). Language and culture in learning: Teaching Spanish to Native Speakers of Spanish. Washington. D.C: Falmer Press / Taylor \& Francis.

Milroy, L. (2001). «Bridging the micro-macro gap: social change, social networks and bilingual repertories», in J. P. Klatter-Folmer and Van Avermaet (eds.), Theories on maintenance and loss of minority languages: Toward a mores integrated explanatory framework. Waxmann Verlag: Münster and New York, 39-64.

Paradis, M. (1998). «Neurolinguistics aspects of the native speakers», in R. Sing (ed.), The Native Speaker: Multilingual Perspectives. New Delhi: Sage, 124-47.

Rodríguez Pino, C. (1997). «Teaching Spanish to Native Speakers: New Perspective in the 1990s», available from http://www.cal.org/resources/archive/news/199709/9709Spanish.html, accessed in 2006.

Roca, A. (1997). «Retrospectives, advances, and current needs in the teaching of Spanish to United States Hispanic bilingual students», in ADFL Bulletin, 29: 37-43.

Roca, A. (2000). «Teaching Spanish to the Hispanic bilingual college student in Miami», in A. Roca (ed.), Research on Spanish in the United States: linguistic issues and challenges. Somerville, Massachusetts: Cascadilla Press, 125-135.

Roca, A. and Colombi, C. (eds.) (2003). Mi lengua: Spanish as a heritage language in the United States, research and practice. Washington, D.C.: Georgetown University Press.

Romaine, S. (1995). Bilingualism. Malden, Massachusetts: Blackwell Publishers.

Scwartz, A. (2003). «!No me suena! Heritage Spanish speakers' writing strategies», in A. Roca and C. Colombi (eds.), Mi lengua: Spanish as a heritage language in the United States, research and practice. Washington, D.C.: Georgetown University Press, 235-256.

Sánchez, R. (1976). «Critique of oral assessment instruments», in Journal of the National Association for Bilingual Education, 1, 2: 120-127.

Sánchez, R. (1981). "Spanish for native speakers at the university: suggestions», in G. Valdés, A. Lozano and R. García-Moya (eds.), Teaching Spanish to the Hispanic Bilingual in the United States: Issues, Aims, and Methods. New York: Teachers College Press, 91-100.

Sánchez, R. (1994). Chicano discourse: socio-historic perspectives. Houston, Texas: Arte Publico Press, University of Houston.

Shannon, S. (1995). «The hegemony of English: a case study of one bilingual classroom as a site of resistance», in Linguistics and Education, 7: 175-200.

Silva-Corvalán, C. (1994). Language Contact and Change. Oxford, U.K.: Clarendon Press. 
Solé, Y. (1981). «Consideraciones pedagógicas en la enseñanza del español a estudiantes bilingües», in G. Valdés, A. Lozano and R. García-Moya (eds.), Teaching Spanish to the Hispanic Bilingual in the United States: Issues, Aims, and Methods. New York: Teachers College Press, 21-29.

Stritikus, (2002). Immigrant children and the politics of English only: views from the classroom. New York: LFB Scholarly Publishing LLC.

Teschner, R. (1981). «Spanish for native speakers: evaluating twenty-five Chicano compositions in a first-year course», in G. Valdés, A. Lozano and R. García-Moya (eds.), Teaching Spanish to the Hispanic Bilingual in the United States: Issues, Aims, and Methods. New York: Teachers College Press, 115-139.

Tse, L. (2001). «Resisting and reversing language shift: Heritage Language Resilience among US native biliterates», in Harvard Educational Review, 71, 4: 676-707.

Tuominen, A. (1999). «Who decides the home language? A look at multilingual families», in International Journal of the Sociology of Language, 140: 59-76.

Valdés, G. (1981). «Pedagogical implications of teaching Spanish to the Spanish-speaking in the United States», in G. Valdés, A. Lozano and R. García-Moya (eds.), Teaching Spanish to the Hispanic Bilingual in the United States: Issues, Aims, and Methods. New York: Teachers College Press, 3-29.

Valdés, G. (1989). «Teaching Spanish to Hispanic bilinguals: A look at oral proficiency testing and the proficiency movement», in Hispania, 73: 392-401

Valdés, G. and Figueroa, R. A. (eds.) (1994). Bilingualism and testing: A special case of bias. Norwood, New Jersey: Ablex.

Valdés, G. (1995). «The teaching of minority languages as academic subjects: Pedagogical and theoretical challenges», in Modern Language Journal, 79: 299-328.

Valdés, G. (1997). «The teaching of Spanish to bilingual Spanish-speaking students: outstanding issues and unanswered questions», in C. Colombi and F. Alarcón (eds.), La enseñanza del español a hispanohablantes: Praxis y teoría. Boston, Massachusetts: Houghton Mifflin, 93-101.

Valdés, G. (1998). «The construct of the near-native speaker in the foreign language profession: Perspectives on ideologies about language», in ADFL Bulletin: 151-60.

Valdés, G. and Geoffrion-Vinci. M. (1998). «Chicano Spanish: The problem of the 'undeveloped' code in bilingual repertoires», in Modern Language Journal, 82: 473-501.

Valdés, G. (2001). «Heritage language students: Profiles and possibilities», in J.K. Peyton and S. McGinnis (eds.), Heritage languages in America: Preserving a national resource. McHenry, Illinois and Washington, DC: Delta, 37-77.

Villa, D. (1996). «Choosing a 'Standard' variety of Spanish for the instruction of Native Spanish Speakers in the US», in Foreign Language Annals, 29: 192-199.

Villa, D. and Villa, J. (1998). "Identity labels and self-reported language use: Implications for Spanish language programs», in Foreign Language Annals, 31: 505-16.

Wei, L. (2002). «Bilingual development and social networks of British-born Chinese children», in International Journal of Sociology of Language, 153: 9-26.

Winsler, A., Díaz, R. Espinosa, L. and Rodríguez, J. (1999). "When learning a second language does not mean losing the first: bilingual language development in low-income Spanishspeaking children attending bilingual preschool», in Child Development, 70, 2: 349-362.

Zentella, A.C. (1997). Growing up bilingual. Malden. Massachusetts: Blackwell Publishers. 